\title{
Effect of Iron Fertilization on Nitrogen and Iron Content, Uptake and Quality Parameters of Groundnut (Arachis hypogaea L.)
}

\author{
Tanuja Poonia ${ }^{1}$, S.R. Bhunia ${ }^{1}$ and Rakesh Choudhary ${ }^{2 *}$ \\ ${ }^{1}$ Department of Agronomy, College of Agriculture, Swami Keshwanand Rajasthan \\ Agricultural University, Bikaner-334006, India \\ ${ }^{2}$ Krishi Vigyan Kendra, Ambala-133004, Haryana, India \\ *Corresponding author
}

\section{Keywords}

Citric acid, FYM,

Groundnut, Iron

Article Info

Accepted:

20 February 2018

Available Online:

10 March 2018

\section{A B S T R A C T}

A field experiment was conducted to study the effect of iron fertilization on nitrogen and iron content, uptake and quality parameters of groundnut (Arachis hypogaea L.) during kharif, 2016 at instructional farm, SKRAU, Bikaner. The results revealed that application of $\mathrm{FeSO}_{4} @ 25 \mathrm{~kg} \mathrm{ha}^{-1}$ as basal + foliar spray of $\mathrm{FeSO}_{4} @ 0.5 \%$ at 45 and $75 \mathrm{DAS}+$ Citric acid @ $0.1 \%$ at 45 and 75 DAS + $5 \mathrm{t} \mathrm{FYM} \mathrm{ha}^{-1}$ significantly increased nitrogen and iron content, uptake and quality parameters of groundnut. Nitrogen and iron content and uptake and protein content in kernels also enhanced with application of $\mathrm{FeSO}_{4} @ 25 \mathrm{~kg} \mathrm{ha}^{-1}$ as basal+Foliar spray of $\mathrm{FeSO}_{4} @ 0.5 \%$ at 45 and 75 DAS+Citric acid @ 0.1\% at 45 and 75 DAS + 5 t FYM ha $^{-1}$. However, oil content was not influenced due to soil and foliar applied iron treatment alone or in combinations. Similarly, Application of FeSO4@ $25 \mathrm{~kg}$ $\mathrm{ha}^{-1}$ as basal + foliar spray of FeSO4 @ 0.5\% at 45 and 75 DAS + Citric acid @ 0.1\% at 45 and 75 DAS +5 t FYM ha $^{-1}$ significantly increased nitrogen and iron content and uptake in kernel over control and at par with foliar spray of FeSO4@0.5\% at 45 and 75 DAS + Citric acid @ $0.1 \%$ at 45 and $75 \mathrm{DAS}+5 \mathrm{t} \mathrm{FYM} \mathrm{ha}^{-1}$ as basal application treatment.

\section{Introduction}

In the Indian oil seed scenario groundnut (Arachis hypogaea L.) is the largest component and occupies $40 \%$ of total oilseeds area, contributing $60 \%$ of total production. It is world's largest source of edible oil and ranks $13^{\text {th }}$ among the food crops and $4^{\text {th }}$ most important oil seed crops of the world. Groundnut seed (kernel) contains 44-50\% oil, $26 \%$ protein and $10-20 \%$ carbohydrate. Groundnut seeds are good source of vitamin E, calcium, phosphorus, magnesium, zinc, iron, riboflavin, thiamine and potassium. Oil extracted from the kernel is used for culinary purpose. The residual i.e. oil cake contains 7 to $8 \% \mathrm{~N}, 1.5 \% \mathrm{P}_{2} \mathrm{O}_{5}$ and $1.2 \% \mathrm{~K}_{2} \mathrm{O}$ and can be used as manure. Among groundnut producing countries of the world, India stands first by occupying about $38 \%$ of total area.

Iron involved in the formation of chlorophyll even though it is not its constituent. Iron is a constituent of large number of metabolically active compounds like cytochromes $\left(b, b_{6}, c_{1}\right.$ and $a_{3}$ ), heme and non-heme enzymes and 
other functional metal proteins such as ferrodoxin and haemoglobin. Thus, best known role of iron is its catalytic function in biological oxidation-reduction and other metabolic processes in plants like oxidative photophosphorylation during cell respiration. It is also known to be involved in carbohydrate metabolism. Yadav (2009) conducted an experiment at Bikaner and observed that increasing $\mathrm{FeSO} 4$ level up to 50 $\mathrm{kg}$ ha-1 increased nutrient $\mathrm{Fe}$ content and nutrient uptake (N, P,S and $\mathrm{Fe}$ ) in kernels, haulm and shell and protein content in kernels of groundnut. Similarly, Meena et al., (2013) showed that the nutrient concentration and their uptake in mungbean was higher due to application of FeSO4 @ $25 \mathrm{~kg}$ ha-1 in comparison to control in Bikaner (Rajasthan).

The $\mathrm{pH}$ has a significant influence on the solubility of iron, which is minimum in $\mathrm{pH}$ range - 7.4 to 8.5 , main charactristic of calcareous soils (Loeppert and Hallmark, 1985). Calcareous soils may contain high levels of total $\mathrm{Fe}$, but in unavailable form. Visible $\mathrm{Fe}$ deficiency or $\mathrm{Fe}$ chlorosis is common in many plant growths in calcareous soil. However, owing to the nature and causes of $\mathrm{Fe}$ chlorosis, leaf $\mathrm{Fe}$ concentrations is not necessarily related to degree of chlorosis. In chlorotic plants iron concentrations can be higher or lower than those in normal plants. Inorganic iron can maintain this level of soluble Fe only in soils with $\mathrm{pH}$ between 5.5 and 6.0.

Foliar sprays of Fe-compound are commonly used as a means of controlling lime induced chlorosis of field crops grown on calcareous soil. But spraying with iron salts alone has been usually found to be relatively less effective because of precipitation of iron from the spray solution and poor translocation of applied iron within the plant (Chen and Barak, 1982). However, poor seed yield of groundnut may result from insufficient iron $(\mathrm{Fe})$ uptake and poor biological nitrogen $(\mathrm{N})$ fixation due to high bicarbonate and $\mathrm{pH}$ in soils in the IGP region of South Asia is lacking. In this backdrop, the objectives of present study were to determine the effect of iron fertilization on nitrogen and iron content, uptake and quality parameters of groundnut

\section{Materials and Methods}

\section{Experimental site, soil and Climate characteristics}

Field experiment was conducted to study the effect of iron fertilization on growth, yield and quality of groundnut (Arachis hypogaea L.) during kharif, 2016 at Instructional Farm, College of Agriculture, Swami Keshwanand Rajasthan Agricultural University, Bikaner $\left(28.01^{\circ} \mathrm{N}\right.$ latitude and $73.22^{\circ} \mathrm{E}$ longitude at an altitude of 234.70 meters above mean sea level).

The soil of the experimental field was loamy sand in texture, alkaline in reaction low in organic carbon low in available nitrogen, medium in available phosphorus and low in available potassium. The initial soil characteristics of the experimental field are presented in table 1.

Experimental site represented the arid climate average annual rainfall of about $\mathrm{mm}$. More than 80 per cent of rainfall is received in kharif season (July-September) by the south west monsoon.

During growing season, the maximum temperature may go as high as $44.4^{\circ} \mathrm{C}$ while in the winters it may fall as low as $14.0^{\circ} \mathrm{C}$ and crop received $340 \mathrm{~mm}$ of rainfall in 21 rainy days in the growing season. Pan evaporation ranged from 5.7 to $15.7 \mathrm{~mm}$ per day during the crop growing period and average relative humidity during the experimental season fluctuated between 43.9 to $76.2 \%$ (Fig. 1). 


\section{Treatments and experimental design}

Twelve iron fertilization treatments viz. control (water spray), $\mathrm{FeSO}_{4}$ basal @ $25 \mathrm{~kg}$ $\mathrm{ha}^{-1}$, foliar spray of citric acid @ $0.1 \%$ at 45 and $75 \mathrm{DAS}$, foliar spray of $\mathrm{FeSO}_{4} @ 0.5 \%$ at 45 and $75 \mathrm{DAS}, \mathrm{FeSO}_{4}$ basal $\left(25 \mathrm{~kg} \mathrm{ha}^{-1}\right)+5$ ton FYM ha ${ }^{-1}, \mathrm{FeSO}_{4}$ basal $\left(25 \mathrm{~kg} \mathrm{ha}^{-1}\right)+$ foliar spray of $\mathrm{FeSO}_{4} @ 0.5 \%$ at 45 and 75 DAS, foliar spray of $\mathrm{FeSO}_{4} @ 0.5 \%$ at 45 and 75 DAS + citric acid @ $0.1 \%$ at 45 and 75 DAS, $\mathrm{FeSO}_{4}$ basal @ $25 \mathrm{~kg} \mathrm{ha}^{-1}+$ citric acid @ $0.1 \%$ at 45 and $75 \mathrm{DAS}+5$ ton FYM ha ${ }^{-1}$, $\mathrm{FeSO}_{4}$ basal @25 kg ha ${ }^{-1}+$ foliar spray of $\mathrm{FeSO}_{4} @ 0.5 \%$ at 45 and $75 \mathrm{DAS}+$ citric acid @ $0.1 \%$ at 45 and 75 DAS, foliar spray of $\mathrm{FeSO}_{4} @ 0.5 \%$ at 45 and $75 \mathrm{DAS}+$ citric acid @ $0.1 \%$ at 45 and $75 \mathrm{DAS}+5$ ton $\mathrm{FYM} \mathrm{ha}^{-1}$, $\mathrm{FeSO}_{4}$ basal @ $25 \mathrm{~kg} \mathrm{ha}^{-1}+\mathrm{FeSO}_{4} @ 0.5 \%$ at 45 and $75 \mathrm{DAS}+5$ ton FYM ha ${ }^{-1}, \mathrm{FeSO}_{4}$ basal @ $25 \mathrm{~kg} \mathrm{ha}^{-1}+$ foliar spray of $\mathrm{FeSO}_{4} @$ $0.5 \%$ at 45 and 75 DAS + citric acid @ 0.1\% at 45 and $75 \mathrm{DAS}+5$ ton $\mathrm{FYM} \mathrm{ha}^{-1}$ were tried in randomized block design with three replications. Crop sown at a distance of $30 \mathrm{~cm}$ and $10 \mathrm{~cm}$ plant to plant distance within row and net plot size $2.4 \mathrm{~m} \mathrm{X} 3.0 \mathrm{~m}$.

\section{Crop establishment and management}

The seed of groundnut variety HNG-10 was sown using $100 \mathrm{~kg}$ seed $\mathrm{ha}^{-1}$ at the depth of 5 $\mathrm{cm}$ on $21^{\mathrm{st}}$ June, 2016 manually in the furrow already opened by hand drawn seed drill. The seed was treated with Chloropyriphos @ $4 \mathrm{ml}$ $\mathrm{kg}^{-1}$ seed just before sowing to ensure protection from soil borne insects and termites.

Hand weeding was done manually 20 and 40 DAS with the help of hand hoe to keep the field weed free. Pre-sowing irrigation (palewa) of $60 \mathrm{~mm}$ was applied before field preparation to ensure uniform and adequate moisture at sowing time and later all irrigation applied on the base of crop requirement.

\section{Treatment application and analysis}

Iron as per treatment was applied through ferrous sulphate $\left(\mathrm{FeSO}_{4} .7 \mathrm{H}_{2} \mathrm{O}\right)$ containing 19 per cent iron and 10.5 per cent sulphur. The weighed quantity of ferrous sulphate was broadcasted uniformly in earmarked plots and thoroughly mixed in soil before sowing. For foliar spray treatment stock solution of 0.5 per cent $\mathrm{FeSO}_{4}$ and 0.1 per cent citric acid were prepared separately. $\mathrm{FeSO}_{4}$ and citric acid was applied using 500 liters of water separately or together as per treatment at 45 and 75 DAS. Similarly, measured quantity of FeSO4along with or without Lime (as per treatment) were mixed in water using 500 liters' water per hectare and sprayed at 45 and 75 DAS. The calculated quantity of chemical fertilizers as per treatment was applied at the time of bed preparation in respective treatment. Urea and Di Ammonium phosphate (DAP) were used as source of nitrogen and phosphorus, respectively.

Seed samples meant for iron determination were first washed with distilled water followed by $0.1 \mathrm{~N} \mathrm{HCl}$ and finally with glass distilled water. After drying in air and then in oven at $70^{\circ} \mathrm{C}$, these samples were finally grinded and digested in di-acid mixture $\left(\mathrm{HNO}_{3}: \mathrm{HClO}_{4}, \quad 3: 1\right.$ ratio). Estimation of nitrogen was done by colorimetric method using spectrophotometer after development of colours with Nessler's reagent. Nitrogen was calculated and express as percentage. Iron in the acid extract was determined by atomic absorption spectrophotometer (Lindsay and Norwell, 1978) and expressed in ppm. A composite sample of 100 gram was drawn from the bulk of the dry pods of each net plot randomly and shelled. The ratio of kernel to pod weight was worked out and expressed in per cent. Oil content in kernel was determined by Soxhlet apparatus using petroleum ether $\left(60-80^{\circ} \mathrm{C}\right)$ as an extractant (A.O.A.C., 1960). Protein per cent in kernels was calculated by 
multiplying nitrogen concentration percentage in kernel by the factor of 6.25 (A.O.A.C., 1960).

\section{Results and Discussion}

Effect of iron fertilization on nitrogen content and uptake in groundnut kernels

An iron fertilization management practices showed significant $(\mathrm{p}=0.05)$ effect on nitrogen content, uptake and protein content (Table 2). Nitrogen content $(3.75 \%)$ in seed was recorded maximum under the treatment $\mathrm{FeSO}_{4}$ @ $25 \mathrm{~kg} \mathrm{ha}^{-1}$ as basal + Foliar spray of $\mathrm{FeSO}_{4}$ @ $0.5 \%$ at 45 and 75 DAS + Citric acid @ $0.1 \%$ at 45 and $75 \mathrm{DAS}+5 \mathrm{t} \mathrm{FYM} \mathrm{ha}^{-1}$ which was significantly higher over control but it was at par with the treatment of Foliar spray of $\mathrm{FeSO}_{4} @ 0.5 \%$ at 45 and 75 DAS + Citric acid @ $0.1 \%$ at 45 and 75 DAS + 5 t FYM $\mathrm{ha}^{-1}$. The increase in nitrogen content was to the tune of 2.87 and 3.75 per cent over control, respectively. Jharia (2002) reported that application of $\mathrm{Fe}$ up to $5 \mathrm{~kg} \mathrm{ha}^{-1}$ significantly increased the nutrient content $\mathrm{N}, \mathrm{P}$, and $\mathrm{K}$ content of seed.

Nitrogen uptake in seed was recorded maximum under the treatment $\mathrm{FeSO}_{4} @ 25 \mathrm{~kg}$ ha-1as basal + Foliar spray of $\mathrm{FeSO}_{4} @ 0.5 \%$ at 45 and 75 DAS + Citric acid @ 0.1\% at 45 and 75 DAS+5 t FYM ha ${ }^{-1}$ followed by foliar spray of $\mathrm{FeSO}_{4} @ 0.5 \%$ at 45 and $75 \mathrm{DAS}+$ Citric acid @ $0.1 \%$ at 45 and 75 DAS + 5 t FYM ha $^{-1}$ (T10) and significantly superior to control (Table 2).

Similarly, Meena et al., (2013) showed that the nutrient concentration and their uptake in mungbean was higher due to application of $\mathrm{FeSO}_{4} @ 25 \mathrm{~kg} \mathrm{ha}^{-1}$ in comparison to control in Bikaner (Rajasthan). Rao et al., (2002) found that application of FYM @ 10 tons ha $^{-1}$ as organic manure increased uptake of $\mathrm{N}$ significantly over the control.

Effect of iron fertilization on protein content and oil yield

Protein content $(23.42 \%)$ in kernel of groundnut were recorded maximum under $\mathrm{FeSO}_{4} @ 25 \mathrm{~kg} \mathrm{ha}^{-1}$ as basal + Foliar spray of $\mathrm{FeSO}_{4} @ 0.5 \%$ at 45 and 75 DAS+ Citric acid @ $0.1 \%$ at 45 and $75 \mathrm{DAS}+5 \mathrm{t} \mathrm{FYM} \mathrm{ha}^{-1}$ followed by $23.38 \%$ under Foliar spray of $\mathrm{FeSO}_{4} @ 0.5 \%$ at 45 and $75 \mathrm{DAS}+$ Citric acid @ $0.1 \%$ at 45 and 75 DAS + 5 t FYM ha $^{-1}$ and the minimum $17.92 \%$ in control (Table 2).

Table.1 Initial status (kharif, 2016) of soil properties at the experimental site

\begin{tabular}{|c|c|c|c|}
\hline Soil properties & Value (0-15 cm.) & Soil properties & Value (0-15 cm.) \\
\hline \multicolumn{2}{|c|}{ A. Mechanical Composition } & C. Chemical properties & \\
\hline Sand $(\%)$ & 85.50 & Organic carbon $(\%)$ & 0.07 \\
\hline Silt $(\%)$ & 7.55 & Available $\mathrm{N}\left(\mathrm{kg} \mathrm{ha}^{-1}\right)$ & 89.25 \\
\hline Clay $(\%)$ & 6.95 & Available $\mathrm{P}_{2} \mathrm{O}_{5}\left(\mathrm{~kg} \mathrm{ha}^{-1}\right)$ & 19.5 \\
\hline Texture & loamy Sand & Available $\mathrm{K}_{2} \mathrm{O}\left(\mathrm{kg} \mathrm{ha}^{-1}\right)$ & 190.35 \\
\hline \multicolumn{2}{|c|}{ B. Physical properties } & Available S (ppm) & 7.3 \\
\hline $\begin{array}{c}\text { Bulk density (Mg m- } \\
\text { 3) }\end{array}$ & 1.63 & Available Fe (ppm) & 1.98 \\
\hline $\begin{array}{c}\text { Particle density (Mg } \\
\mathbf{m}^{-3} \text { ) }\end{array}$ & 2.66 & $\begin{array}{c}\mathrm{EC}\left(\mathrm{dS} \mathrm{\textrm {m } ^ { - 1 }}\right)(1: 2 \text { soil water } \\
\left.\text { suspension at } 25^{0} \mathrm{C}\right)\end{array}$ & 0.15 \\
\hline Porosity $(\%)$ & 37.80 & $\begin{array}{c}\text { Soil pH (1:2 soil water suspension } \\
\left.\text { at } 25^{\circ} \mathrm{C}\right)\end{array}$ & 8.38 \\
\hline
\end{tabular}


Table.2 Effect of iron fertilization on nitrogen content, uptake and Protein content in groundnut kernels

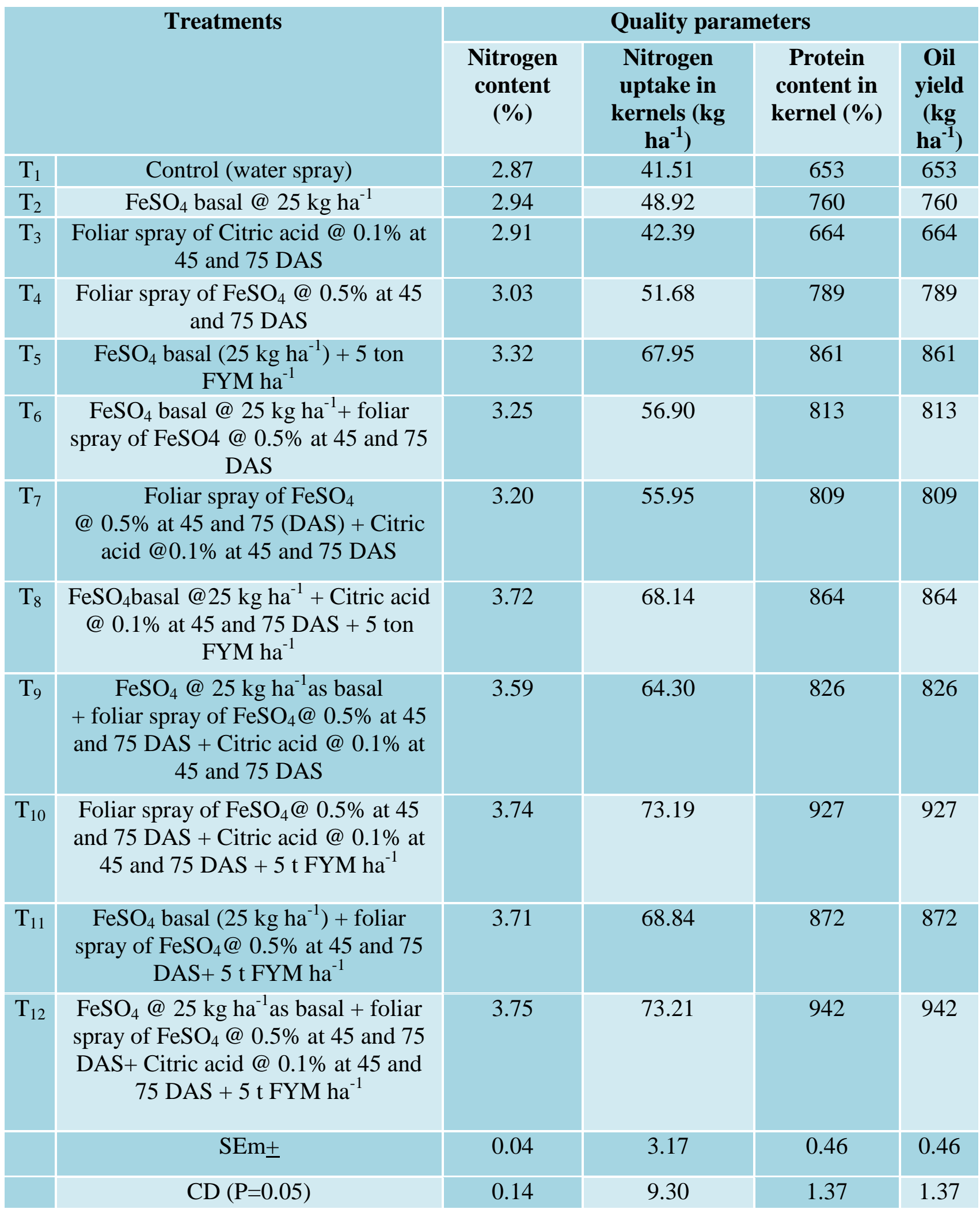


Table.3 Effect of iron fertilization on Iron content and uptake in groundnut kernel

\begin{tabular}{|c|c|c|c|}
\hline \multicolumn{2}{|r|}{ Treatment } & \multirow{2}{*}{$\begin{array}{c}\text { Iron content in } \\
\text { kernel } \\
\text { (ppm) }\end{array}$} & \multirow{2}{*}{$\begin{array}{c}\text { Iron uptake } \\
\begin{array}{c}\left(\mathbf{g ~ h a}^{-1}\right) \text { in } \\
\text { kernel }\end{array} \\
385.87\end{array}$} \\
\hline $\mathrm{T}_{1}$ & Control (water spray) & & \\
\hline $\mathrm{T}_{2}$ & $\mathrm{FeSO}_{4}$ basal @25 kg ha ${ }^{-1}$ & 292.70 & 491.84 \\
\hline $\mathrm{T}_{3}$ & Foliar spray of Citric acid @ $0.1 \%$ at 45 and 75 DAS & 266.58 & 392.68 \\
\hline $\mathrm{T}_{4}$ & Foliar spray of $\mathrm{FeSO}_{4} @ 0.5 \%$ at 45 and $75 \mathrm{DAS}$ & 304.36 & 519.13 \\
\hline $\mathrm{T}_{5}$ & $\mathrm{FeSO}_{4}$ basal $\left(25 \mathrm{~kg} \mathrm{ha}^{-1}\right)+5$ ton FYM ha ${ }^{-1}$ & 396.21 & 723.75 \\
\hline $\mathrm{T}_{6}$ & $\begin{array}{l}\mathrm{FeSO}_{4} \text { basal @ } 25 \mathrm{~kg} \mathrm{ha}^{-1}+\text { foliar spray of } \mathrm{FeSO}_{4} @ 0.5 \% \text { at } 45 \text { and } \\
75 \text { DAS }\end{array}$ & 389.22 & 679.50 \\
\hline $\mathrm{T}_{7}$ & $\begin{array}{l}\text { Foliar spray of } \mathrm{FeSO}_{4} @ 0.5 \% \text { at } 45 \text { and } 75 \text { (DAS) + Citric acid @ } \\
0.1 \% \text { at } 45 \text { and } 75 \mathrm{DAS}\end{array}$ & 387.23 & 676.91 \\
\hline $\mathrm{T}_{8}$ & $\begin{array}{l}\mathrm{FeSO}_{4} \text { basal @ } 25 \mathrm{~kg} \mathrm{ha}^{-1}+\text { Citric acid @ } 0.1 \% \text { at } 45 \text { and } 75 \text { DAS + } \\
5 \text { ton FYM ha }\end{array}$ & 396.22 & 725.25 \\
\hline $\mathrm{T}_{9}$ & $\begin{array}{l}\mathrm{FeSO}_{4} @ 25 \mathrm{~kg} \mathrm{ha}^{-1} \text { as basal + foliar spray of } \mathrm{FeSO}_{4} @ 0.5 \% \text { at } 45 \\
\text { and } 75 \mathrm{DAS}+\text { Citric acid @ } 0.1 \% \text { at } 45 \text { and } 75 \mathrm{DAS}\end{array}$ & 393.88 & 705.60 \\
\hline $\mathrm{T}_{10}$ & $\begin{array}{l}\text { Foliar spray of } \mathrm{FeSO}_{4} @ 0.5 \% \text { at } 45 \text { and } 75 \mathrm{DAS}+\text { Citric acid @ } \\
0.1 \% \text { at } 45 \text { and } 75 \mathrm{DAS}^{-5} \mathrm{t} \mathrm{FYM} \mathrm{ha}{ }^{-1}\end{array}$ & 401.91 & 786.61 \\
\hline $\mathrm{T}_{11}$ & $\begin{array}{l}\mathrm{FeSO}_{4} \text { basal }\left(25 \mathrm{~kg} \mathrm{ha}^{-1}\right)+\text { foliar spray of } \mathrm{FeSO}_{4} @ 0.5 \% \text { at } 45 \text { and } \\
75 \mathrm{DAS}+5 \mathrm{t} \mathrm{FYM} \mathrm{ha}^{-1}\end{array}$ & 395.88 & 734.54 \\
\hline $\mathrm{T}_{12}$ & $\begin{array}{l}\mathrm{FeSO}_{4} @ 25 \mathrm{~kg} \mathrm{ha}^{-1} \text { as basal + foliar spray of } \mathrm{FeSO}_{4} @ 0.5 \% \text { at } 45 \\
\text { and } 75 \mathrm{DAS}+\text { Citric acid @ } 0.1 \% \text { at } 45 \text { and } 75 \mathrm{DAS}+5 \mathrm{t} \mathrm{FYM} \mathrm{ha}^{-1}\end{array}$ & 404.50 & 789.86 \\
\hline & $\mathrm{SEm} \pm$ & 2.15 & 31.14 \\
\hline & $\mathrm{CD}(\mathrm{P}=0.05)$ & 6.31 & 91.35 \\
\hline
\end{tabular}

Fig.1 Mean weekly meteorological data recorded during crop growing season, 2016

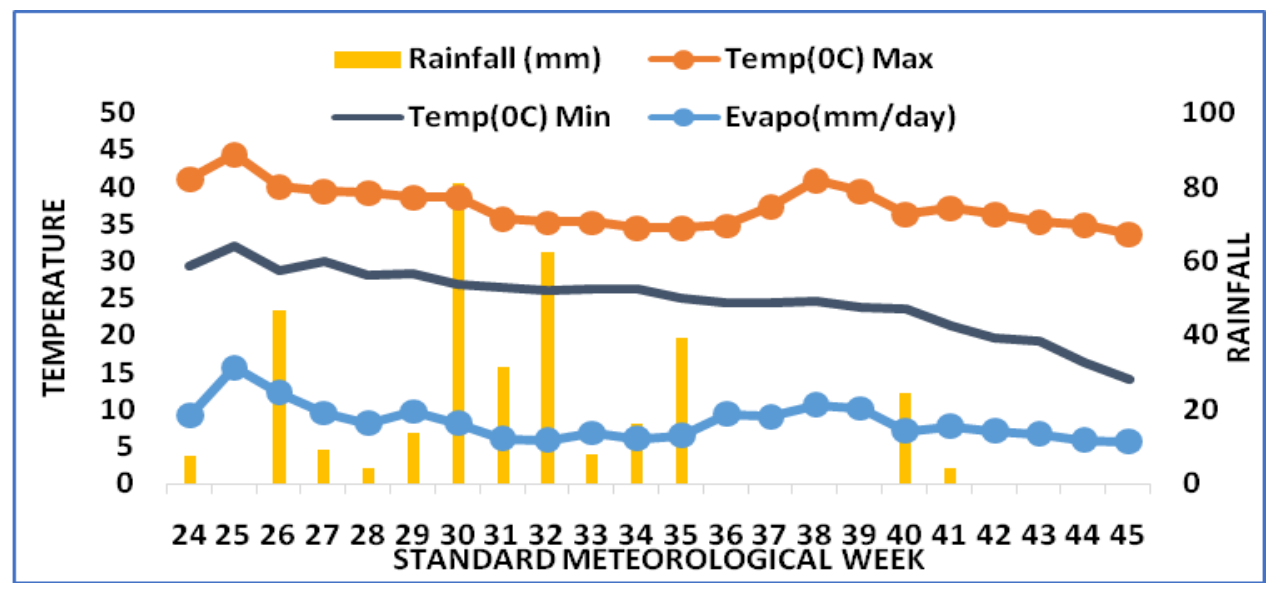

An Iron fertilization had significant effect on oil yield and highest oil yield $\left(942 \mathrm{Kg} \mathrm{ha}^{-1}\right)$ was recorded with $\mathrm{FeSO}_{4}$ @ $25 \mathrm{~kg} \mathrm{ha}^{-1}$ as basal + Foliar spray of $\mathrm{FeSO}_{4} @ 0.5 \%$ at 45 and 75 DAS + Citric acid @ 0.1\% at 45 and 75 DAS +
$5 \mathrm{t} \mathrm{FYM} \mathrm{ha-1} \mathrm{followed} \mathrm{by} \mathrm{Foliar} \mathrm{spray} \mathrm{of} \mathrm{FeSO}_{4}$ @ $0.5 \%$ at 45 and 75 DAS + Citric acid @ $0.1 \%$ at 45 and 75 DAS + $5 \mathrm{t} \mathrm{FYM} \mathrm{ha}^{-1}$ (T10) which gave oil yield of $927 \mathrm{~kg} \mathrm{ha}^{-1}$ (Table 2). Higher oil yield may be due to higher iron 
availability in alkaline soils of Rajasthan, which ensured better biosynthesis of oil in groundnut. Yadav (2009) conducted an experiment at Bikaner and observed that increasing $\mathrm{FeSO}_{4}$ level up to $50 \mathrm{~kg} \mathrm{ha}^{-1}$ increased protein content in kernels of groundnut.

\section{Effect of iron fertilization on iron content and uptake}

Significantly higher iron content (404.50 ppm) and uptake by kernel of groundnut recorded under the treatment $\mathrm{FeSO}_{4} @ 25 \mathrm{~kg} \mathrm{ha}^{-1}$ as basal + Foliar spray of $\mathrm{FeSO}_{4} @ 0.5 \%$ at 45 and 75 DAS + Citric acid @ $0.1 \%$ at 45 and 75 DAS + $5 \mathrm{t}$ FYM ha ${ }^{-1}$ followed by foliar spray of $\mathrm{FeSO}_{4} @ 0.5 \%$ at 45 and $75 \mathrm{DAS}+$ Citric acid @ $0.1 \%$ at 45 and $75 \mathrm{DAS}+5 \mathrm{t} \mathrm{FYM} \mathrm{ha}^{-1}\left(\mathrm{~T}_{10}\right)$ which recorded $786.61 \quad \mathrm{~kg}$ ha $^{-1}$ iron uptake by kernel (Table 3). Anita Mann et al., (2015) conducted a field study to evaluate the effect of iron source through foliar as well as basal applications of iron increased active Fe content in groundnut.

\section{Acknowledgements}

We also acknowledge the financial support and facilities provided by college of agriculture Bikaner and S.K. Rajasthan Agricultural University, Bikaner (Rajasthan), India to carry out this research. Senior author is grateful to all those who contributed directly and indirectly during the course of his M.Sc research.

\section{References}

A.O.A.C. 1960. Official methods of analysis. $18^{\text {th }}$ Ed., Association of Official
Agriculture Chemist, Washington DC, pp. 506-508.

Anita, M., Singh, A.L., Shubhangi, O., Goswami, N., Mehta, D. and Chaudhari, V. 2015. Effect of iron source on iron deficiency induced chlorosis in groundnut. Legume Research. 40(2): 241249.

Chen, Y., Barak, P. 1982. Iron Nutrition of Plants in Calcareous Soils. Advances in Agronomy. 35: 217-240.

Jharia, A. 2002. Effect of iron fertilization and thiourea spray on the productivity of cluster bean (Cyamopsis tetragonoloba L.). M.Sc. (Ag.) thesis, Raj. Agri. I Uni., Bikaner.

Lindasy, W. L. and Norvell, W. A. 1978. Development of DTPA soil test for zinc, iron, manganese and copper. Soil Science Society of America Journal. 42: 421-428.

Loeppert, R. H. and C.T. Hallmark. 1985. Indigenous soil properties influencing the availability of iron in calcareous soils. Soil Science Society of America Journal. 49: 597-603.

Meena, K.K., Meena, R. S. and Kumawat, S. M. 2013. Effect of sulphur and iron fertilization on productivity of mungbean. Indian Journal of Agriculture Sciences. 83(4): 472-476.

Rao, S.S. and Shaktawat, M. S. 2002. Effect of organic manure, phosphorus and gypsum on groundnut (Arachis hypogaea L.) production under rainfed condition. Indian Journal of Agronomy.47: 234-241.

Yadav, M.K. 2009. Effect of iron fertilization and thiourea application on growth and yield of groundnut in western Rajasthan. M.Sc. Thesis, SKRAU, Bikaner.

\section{How to cite this article:}

Tanuja Poonia, S.R. Bhunia and Rakesh Choudhary. 2018. Effect of Iron Fertilization on Nitrogen and Iron Content, Uptake and Quality Parameters of Groundnut (Arachis hypogaea L.). Int.J.Curr.Microbiol.App.Sci. 7(03): 2297-2303. doi: https://doi.org/10.20546/ijcmas.2018.703.269 